\title{
Selected Webliographies on Indonesian Cultural Heritages
}

\author{
Ika Krismayani $^{1 *}$, Jumino ${ }^{2}$, and Joko Wasisto ${ }^{3}$ \\ 1,2,3 Library Sciences Department, Diponegoro University, Tembalang, Semarang City, \\ Central Java, Indonesia, 50275
}

\begin{abstract}
Indonesia is a country rich in cultural heritage. The diverse cultural heritages demand promotion through various media, such as the web, aimed primarily at the younger generation. This paper aims to present various links and descriptions of web-shaped information sources that participate in promoting the cultural heritage of the Nusantara. The method used is a qualitative descriptive method by searching websites through a search engine using predetermined keywords. The results showed that various websites were found to provide information and promote cultural heritage to the broader community. Dissemination was not only carried out to the Indonesian people but also to the international community. This can be seen from two things, namely the nature of web pages that can be accessed globally and the existence of websites using bilingual, namely Indonesian and English.
\end{abstract}

\section{Introduction}

Indonesia Indonesia is an archipelago that is rich in cultural treasures. This is because apart from being composed of tens of thousands of islands, Indonesia is also inhabited by thousands of tribes who are spread from Sabang to Merauke. Each of these ethnics has very diverse languages and cultures.

For a nation and a country, culture is priceless wealth. Therefore, a nation needa to continue to protect and preserve the culture they have. One way is by collecting and disseminating information related to existing cultural treasures. One of the activities to disseminate information about existing cultural treasures is through cultural promotion activities.

In general, promotion is an effort to market a product or service that is owned [1]. The term "Do not know, then do not love" is an appropriate term used to describe the importance of promoting Indonesian cultural treasures. The promotion of cultural treasures is aimed at marketing and informing the existing culture to make people more familiar with their culture and appreciate and love the nation's wealth more. Besides, when the promotion of cultural treasures goes well, of course, it will also impact the tourism of an area. It is hoped that these

*Corresponding author: krismayaniika@gmail.com 
cultural treasures can become tourism destinations, both from domestic and foreign ones. Therefore, promotion is not only aimed at the Indonesian people but also the international community.

Technological advances have encouraged more developed promotional activities in print media and the online world. Those who are technology literate will certainly not waste the opportunity to carry out promotions through online media [2]. One of them is through the media websites. "Both government and community have carried out the use of online media in cultural heritage promotion activities although it has not been thoroughly done. Digital technology very helpful for promotion programs data-driven cultural heritage, providing useful information" [3].

Currently, many websites promote the cultural treasures owned by the Indonesian people. These various websites provide much information with their respective information styles. Therefore, it is essential to compile a webliography with information on a list of websites that promote the Indonesian people's cultural treasures. This paper intends to compile a webliography that contains a list of these websites. Thus, the primary purpose of this study is to describe various sources of information originating from websites. The websites meant are websites that contain information on the promotion of the Indonesian cultural heritage.

\section{Literature Review}

Cultural Cultural heritage is a product or cultural result that comes from various traditions and different spiritual achievements and becomes a group or nation [4]. In Indonesia, the terms tangible cultural heritage and intangible cultural heritage are known. The tangible cultural heritage refers to cultural heritage that can be sensed with the eyes and hands. In contrast, intangible cultural heritage is a cultural heritage that cannot be sensed with the eyes and hands but is actually around the community [5]. Cultural heritage objects can be exemplified such as temples, artefacts, and others. At the same time, intangible cultural heritage can be exemplified, such as Pencak silat, Saman dance, puppet performances, and others.

Currently, these various cultural heritages have been widely promoted through websites. Information about the cultural heritage is available on various platforms. Therefore, it is necessary to compile a bibliographical list containing a list of websites about the cultural heritage of the Indonesian nation. The bibliographic list containing the web list is then known as a webliography."Webliography is an enumerative list of hypertext links and a gateway to the scientific sources of information on the internet" [6]. Webliography is a combination of two words, namely "Web" and "Bibliography". In particular, a webliography can be defined as a list of information sources accessed through the World Wide Web. The list contains specific topics that can be used and cited as scientific papers [7]. In addition to scientific papers, webliography can also help provide information on prescription drugs recommended for consumers and health care providers [8].

The initial step in compiling a webliography is carried out by searching, finding, evaluating, and selecting relevant sources of information [9]. Furthermore, the results of the search are then listed in the form of a list. In general, there is no specific format in the preparation and development of a webliography [10]. However, in general, bibliographic information such as author, title, website address, publisher, and publication date are included. The various bibliographic information listings are then arranged alphabetically or chronologically following the APA or MLA citation format. 


\section{Research Method}

This research is basic research with a case study type. Data collection techniques were carried out through documentation techniques in browsing websites containing information about Indonesian cultural treasures. The website in question can come from government agencies or private institutions. The search results were then analyzed descriptively qualitatively. The results of those searches are then displayed to describe what information is uploaded on each website. The arrangement of the webliography in this article is arranged alphabetically in the following order.

1. Title of information source, containing the title of the source of information in the form of the name of the website or the name of the organization or institution that publishes the website.

2. Site address, containing the address of the website intended.

3. Short annotation, containing brief information about the contents of the websites.

\section{Indonesian Culture: A Selected Webliographies}

As an initial step in compiling a webliography, the writer has conducted a search using the Google search engine using the keywords "Indonesian Culture" and "Indonesian Heritage". Based on this search, several websites used the international language (English) and contained information about various Indonesian cultures. The various websites found are then presented alphabetically as follows.

\subsection{Authentic Indonesia: Travel with Passion (https://authentic- indonesia.com/}

This site is a travel agency site that was formed in 1999. Information about Indonesian culture is packaged based on tourist destinations that are worth visiting. This site also offers tour packages with a wide selection of attractive destinations at competitive prices.

\subsection{Bali.com. (https://bali.com/}

Bali is one of the islands that has its own popularity over other regions in Indonesia. In fact, there is an anecdote that the international community is more familiar with Bali than Indonesia. The Bali.com site provides all information related to Bali. Starting from tourism destinations, cultural events, lodging, and other things needed by tourists, both local, national, and international tourists.

\subsection{Indonesian Cultural Festival (http://www.indoculfest.com/}

As the name implies, the Indonesian Cultural Festival is a website that contains information about Indonesian cultural festivals. Information is presented complete with photos, videos, times, and places of activities, as well as entrance tickets to enjoy the cultural festivals being held.

\subsection{Indonesia Heritage (http://indonesiaheritage.orgh}

IndonesiaHeritage.org is a website that is managed under the auspices of the Pusaka Saujana Indonesia Foundation. This site is a forum for various kinds of information that aims to preserve the treasures of the nation's cultural heritage. The information displayed is in the 
form of articles and news about cultural treasures, the results of media transfer and publications in a digital form related to cultural information, as well as information about museums in Indonesia. In addition to providing information through the website, IndonesiaHeritage.org also provides information in the form of a smartphone application through I-Heritage Apps.

\subsection{Indonesian Heritage Series (http://nusantara.com/heritage/}

This site is part of the site http://nusantara.com/. This web page displayed is part of a 15volume illustrated encyclopaedia series published in 1996. Some of the information displayed on the web page is brief information about Borobudur temple, Panji stories, photos of Bugis boats, and others.

\subsection{Indonesian Heritage Societies (https://heritagejkt.orgh}

This site is the official website of a non-profit organization under the name Indonesian Heritage Societies which was founded in 1970. The organization was founded by the Indonesian people and expatriates who care about the cultural heritage in Indonesia. In addition to informing about the profile of the organization, this site also contains various kind of information on cultural heritage such as virtual heritage tours, cultural workshops, preserving Indonesian heritage, and others.

\subsection{Indonesia Travel: The Official website of Indonesia tourism (https://www.indonesia.travel/gb/en/home/)}

This site is the official website of the Ministry of Tourism and Creative Economy of the Republic of Indonesia. It contains information about various tourist destinations in Indonesia and equipped with selected tourist destinations, This site is one of the official websites established by the government with the most complete cultural and tourist information.

\subsection{Living in Indonesia: A site for Expatriates (https://www.expat.or.id/}

The site, which was set up in 1997 by a group of volunteers, is specifically aimed at expatriates living in Indonesia. Various interesting information about how to live in Indonesia is presented on this site. Advice dealing with daily problems, vacation spots, knowing how to adjust to the culture that exists in Indonesia, finding places to buy something needed are presented on this site. This site is also equipped with a discussion forum on a separate website with the address http://www.livinginindonesiaforum.org/.

\subsection{Perpustakaan Nasional Republik Indonesia (https://www.perpusnas.go.id/?lang=en/)}

The National Library of the Republic of Indonesia is one type of libraries in Indonesia. As a manifestation of one of its functions, namely the cultural function, the National Library of the Republic of Indonesia also provides variety of information related to the Indonesian culture. This information is grouped into several sections, namely Batavia Digital (http://bataviadigital.perpusnas.go.id/), $\quad$ Temple in Indonesia (http://candi.perpusnas.go.id/), Indonesian Film Documentation (http://perfilman.perpusnas.go.id/), Indonesian Literature Documentation (http://sastra.perpusnas.go.id/), Archipelago Palace (http://keraton.perpusnas.go.id/), 
Archipelago Manuscripts (http://pernaskahan.perpusnas.go.id/), and Indonesian Heritage (http://pusakaindonesia.perpusnas.go.id/).

\subsection{Sulawesi Experience.com (https://www.sulawesi-experience.com/}

This site is managed by PT. Antara Wisesa ${ }^{\text {TM}}$ - Cempaka Travel. Similar to Bali.com, this site informs everything about Sulawesi. Various tourist experiences are offered in the form of culture, heritage, adventure, history, beach, nature, and underwater tours.

\section{Conclusion}

Based on the research results above, it can be seen that basic information about Indonesian cultural heritage has been widely promoted by various sites, ranging from websites managed by government agencies and websites managed by private individuals and institutions. These various websites provide information that varies according to the characteristics of each website.

The webliographies compiled are expected to be one of the initial studies to provide sources of information related to existing cultural heritage. The nature of the website that is constantly evolving and undergoing changes makes it necessary to have similar bibliographies that contain more up-to-date information dealing with the Indonesian cultural heritage. Therefore, it is necessary to develop a specific website that provides automatic updates regarding websites about heritages. Thus, any information related to cultural heritage presented in the community should be updated continually.

The writer would like to thank the Faculty of Humanities, Diponegoro University, for providing funding for the implementation of this research. The writer would also like to thank all those who contributed to the implementation of this research.

\section{References}

1. C. Halim, Tip Praktis Promosi Online untuk Berbagai Event, Jakarta: Elex Media Komputindo (2010)

2. E. R. Lubis, Panduan Cepat dan Mudah Belajar Internet Marketing, Jakarta: Buana Ilmu Populer (2018)

3. Balitbang Kemendikbud, Pemanfaatan Media Online dalam Promosi Warisan Budaya, Jakarta: Balitbang Kemendikbud (2017)

4. G. Davidson, C. Mc Conville, A Heritage Handbook, St. Leonard, NSW: Allen \& Unwin (1991)

5. S. Suryaningsum, A. S. Hartati, Wedang Uwuh, Klaten: Nugra Media (2018)

6. D. Alimuhammadi, "Annotated Webliography of Webliographies: a Proposal", The Elec. Lib., 23 (2), pp.168-172 (2005)

7. H. H. Yang, Bloging mind on web-based educational projects, in H. Song, T. Kidd, Handbook of Research on Human Performance and Intructional Technology, New York: Information Science Reference (2010)

8. Y. Ko MS, M. Brown, R. Frost BR, R.L Woosley MB., "Brief Report: Development of a Prescription Medication Information Webliography for Consumers", J. Gen. Inter. Med., 21 (12), pp.1313-1316 (2006) 
9. H. Yang, Webliography: Conception and development, in L. A. Tomei, Encyclopedia of Information Technology Curriculum Integration, New York: Information Science Reference (2008)

10. C. J. Bonk, K. Zhang, Empowering Online Lewarning: 100+ Activities for reading, reflecting, displaying, and doing, San Francisco: Jossey-Bass (2008) 